The University of Maine

\title{
DigitalCommons@UMaine
}

Earth Science Faculty Scholarship

Earth Sciences

1990

\section{Age of the Peach Springs Tuff, Southeastern California and Western Arizona}

\author{
J. E. Nielson \\ Daniel R. Lux \\ University of Maine-Main, dlux@maine.edu \\ G. B. Dalrymple
}

A. F. Glazner

Follow this and additional works at: https://digitalcommons.library.umaine.edu/ers_facpub Part of the Earth Sciences Commons

\section{Repository Citation}

Nielson, J. E.; Lux, Daniel R.; Dalrymple, G. B.; and Glazner, A. F., "Age of the Peach Springs Tuff, Southeastern California and Western Arizona" (1990). Earth Science Faculty Scholarship. 8.

https://digitalcommons.library.umaine.edu/ers_facpub/8 


\title{
Age of the Peach Springs Tuff, Southeastern California and Western Arizona
}

\author{
J. E. Nielson, ${ }^{1}$ D. R. Lux, ${ }^{2}$ G. B. Dalrymple, ${ }^{1}$ and A. F. Glazner ${ }^{3}$
}

\begin{abstract}
Sanidine separates from pumice of the early Miocene Peach Springs Tuff are concordantly dated at $18.5 \pm 0.2 \mathrm{Ma}$ by two isotopic techniques. The Peach Springs Tuff is the only known unit that can be correlated between isolated outcrops of Miocene strata from the central Mojave Desert of southeastern California to the western Colorado Plateau in Arizona, across five structural provinces, a distance of $350 \mathrm{~km}$. Thus the age of the Peach Springs Tuff is important to structural and paleogeographic reconstructions of a large region. Biotite and sanidine separates from bulk samples of the Peach Springs Tuff from zones of welding and vapor-phase alteration have not produced consistent ages by the K-Ar method. Published ages of mineral separates from 17 localities ranged from 16.2 to $20.5 \mathrm{Ma}$. Discordant ${ }^{40} \mathrm{Ar} /{ }^{39} \mathrm{Ar}$ incremental release spectra were obtained for one biotite and two of the sanidine separates. Ages that correspond to the last gas increments are as old as $27 \mathrm{Ma}$. The ${ }^{40} \mathrm{Ar} /{ }^{39} \mathrm{Ar}$ incremental release determinations on sanidine separated from blocks of Peach Springs Tuff pumice yield ages of $18.3 \pm 0.3$ and $18.6 \pm 0.4 \mathrm{Ma}$. Laser fusion measurements yield a mean age of $18.51 \pm$ 0.10 . The results suggest that sanidine and biotite $\mathrm{K}-\mathrm{Ar}$ ages older than about $18.5 \mathrm{Ma}$ are due to inherited Ar from pre-Tertiary contaminants, which likely were incorporated into the tuff during deposition. Sanidine $\mathrm{K}-\mathrm{Ar}$ ages younger than $18 \mathrm{Ma}$ probably indicate incomplete extraction of radiogenic ${ }^{40} \mathrm{Ar}$, whereas laser fusion dates of biotite and hornblende younger than $18 \mathrm{Ma}$ likely are due to postdepositional alteration. Laser fusion ages as high as $19.01 \mathrm{Ma}$ on biotite grains from pumice suggest that minerals from pre-Tertiary country rocks also were incorporated in the magma chamber.
\end{abstract}

\section{INTRODUCTION}

A distinctive sphene-bearing ignimbrite is found in lower Miocene sedimentary and volcanic sequences in a region from Barstow, California, to the western margin of the Colorado Plateau in Arizona (Figure 1) [Goff et al., 1983; Glazner et al., 1986]. The tuff is grey to pink in color and at most localities it is incipiently to highly welded. The phenocryst assemblage is dominated by large sanidine crystals that show a flash of blue color in some orientations (adularescence). Grains of sphene are observable in most hand samples.

This tuff was first described for localities on the Colorado Plateau by Young [1966] and Young and Brennan [1974], who named it the Peach Springs Tuff for the easternmost location that then was known. Young [1966] correlated occurrences of the unit from the Colorado Plateau to localities as far west as Kingman, Arizona. The Peach Springs Tuff later was mapped by Suneson and Lucchitta [1979] in block-faulted terranes to the southwest of Kingman and by Carr et al. [1980], Carr and Dickey [1980], Dickey et al. [1980], Suneson [1980], and Pike and Hansen [1982] in tilted Miocene strata of the Colorado River valley, in both California and Arizona. Reconnaissance by K. A. Howard (oral communication, 1983) showed that an identical tuff could be found overlying tilted deposits related to the Whipple Mountains extensional terrane as far west as the Ship Mountains of California.

Glazner et al. [1986] noted that a single tuff of similar lithology and stratigraphic position to the Peach Springs Tuff

\footnotetext{
${ }^{1}$ U.S. Geological Survey, Menlo Park, California.

${ }^{2}$ Department of Geological Sciences, University of Maine, Orono. Hill.

${ }^{3}$ Department of Geology, University of North Carolina, Chapel

Copyright 1990 by the American Geophysical Union.

Paper number 89JB01290.

0148-0227/90/89JB-01290\$05.00
}

was mapped by Durrell [1953] and T. W. Dibblee [e.g., Dibblee, 1966; Dibblee and Bassett, 1966] in many ranges of the central Mojave Desert (for complete citations, see Glazner et al. [1986]). This unit crops out extensively in the Cady Mountains, where Glazner [1981] informally called it "Redfire tuff." This tuff can be traced from the central Mojave mountain ranges eastward to the Marble and Ship Mountains. Glazner et al. [1986] proposed that the Peach Springs, Redfire tuff, and tuffs mapped by T. W. Dibblee [see Glazner et al., 1986] are the same unit, based on the distribution, general thickness variations, and available stratigraphic and petrological data. This proposed correlation has been supported by work on the suite of heavy minerals [Gusa et al., 1987], which distinguishes the Peach Springs Tuff from tuffs of local occurrence in the region.

Additional support for the correlation of the Peach Springs Tuff comes from paleomagnetic studies. Young and Brennan [1974] showed that the Peach Springs Tuff on the Colorado Plateau has an unusually paleomagnetic direction, when compared to the mean Miocene magnetic pole. Recent paleomagnetic measurements on proposed Peach Springs Tuff from many of the localities shown in Figure 1 [Wells and Hillhouse, 1989] confirm the correlation. Since the correlation was proposed, new localities of the Peach Springs Tuff have been discovered in California, Arizona, and Nevada; currently known locations are represented in Figure 1.

The Peach Springs Tuff thus is the only laterally persistent unit found in nearly every Miocene stratigraphic section of a region that includes the Colorado Plateau, Arizona Transition Zone, Colorado River extensional corridor [Howard and John, 1987], Basin and Range of southern Nevada, and the central Mojave Desert. Because it was deposited in a short period of time (days to weeks [Valentine et al., 1989]), the Peach Springs Tuff represents a singular chronostratigraphic horizon in a region that otherwise lacks such units. It can be used to correlate between adjacent areas that were variably affected by extensional tectonism during the early 


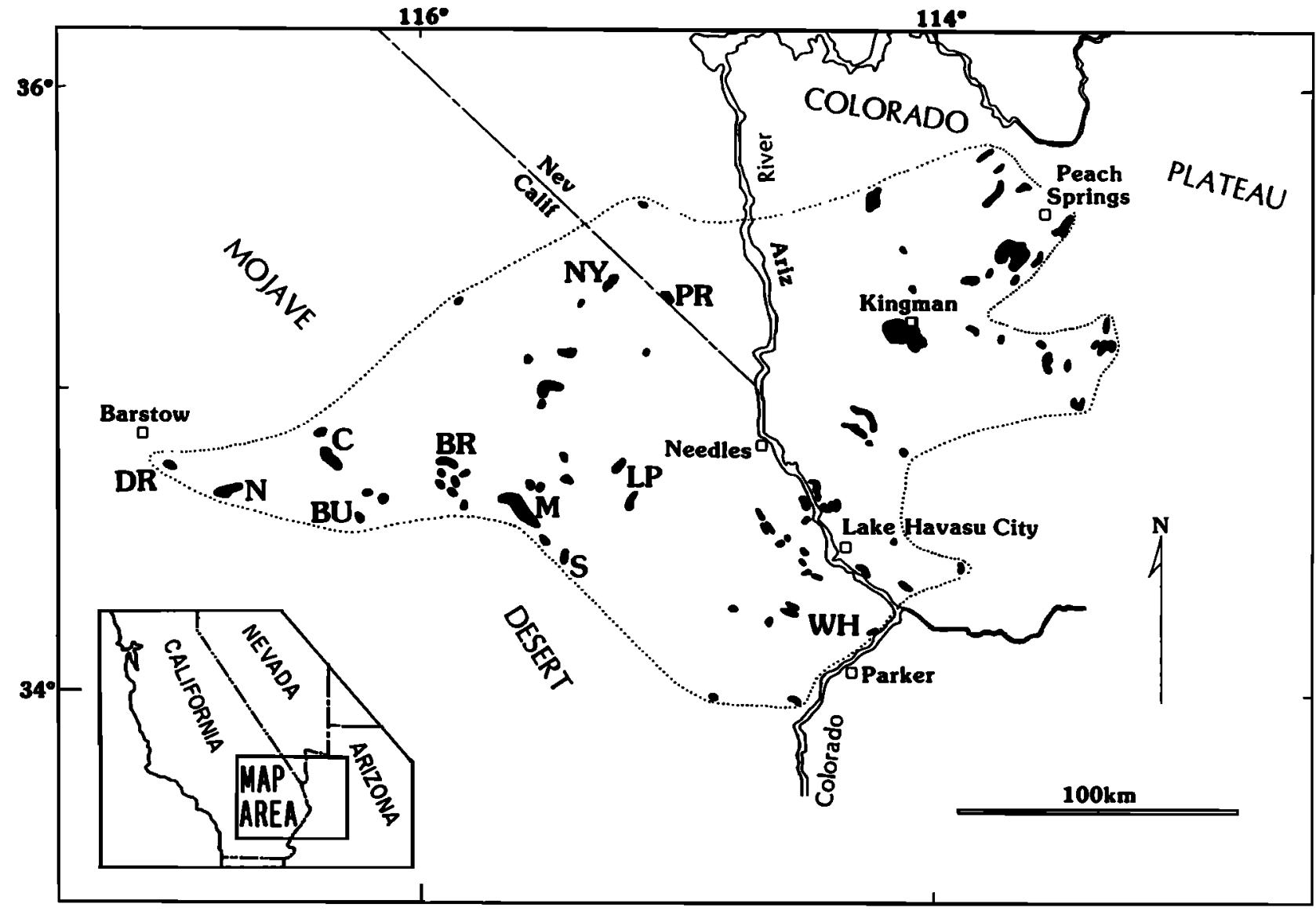

Fig. 1. Map showing distribution of Peach Springs Tuff. Abbreviations of ranges in California: BR, Bristol Mountains; BU, Bullion Mountains; C, Cady Mountains; DR, Daggett Ridge; LP, Little Piute Mountains; M, Marble Mountains; NY, New York Mountains; PR, Piute Range; S, Ship Mountains; WH, Whipple Mountains.

Miocene, and thus it can constrain regional tectonic reconstructions [e.g., Davis, 1986; Glazner et al., 1989].

\section{Previous Work}

Prior to correlation of the unit, conventional K-Ar ages were determined on mineral separates from the Peach Springs Tuff sampled at 17 different localities, in the Colorado Plateau, Colorado River valley, and central Mojave Desert (Table 1). All of these bulk samples were from matrix-rich vitrophyric, devitrified, and welded zones of the tuff; none were samples primarily from pumice. The $\mathrm{K}-\mathrm{Ar}$ ages of sanidine separates from these samples ranged from 16 to $20.5 \mathrm{Ma}$ (15 ages). Biotite ages from four samples ranged from 18.7 to $20.1 \mathrm{Ma}$. A histogram of these ages (Figure 2) has a peak between 17.5 and $19.4 \mathrm{Ma}$; the mean of these values gives an age of $18.3 \pm 0.5 \mathrm{Ma}$. Three of the biotite ages were essentially concordant with dates for sanidine separates from the same sample (Table 1). These data pointed to an age of 19.2 Ma for the Peach Springs Tuff [Nielson et al., 1988], which is older than the sample average. One fission track age determination on sphene (by P. Green, University of Melbourne) produced an age of $18.7 \pm 1.5 \mathrm{Ma}$ (C. Miller, oral communication, 1988).

\section{Design of STUdy}

The objective of the present study was to use ${ }^{40} \mathrm{Ar} /{ }^{39} \mathrm{Ar}$ dating techniques both to determine the most likely age of the Peach Springs Tuff and to identify causes of the variation in ages produced by the conventional $\mathrm{K}$-Ar method. Four separates, three of sanidine and one biotite, were chosen for dating by the ${ }^{40} \mathrm{Ar} /{ }^{39} \mathrm{Ar}$ incremental heating method. Concordant $\mathrm{K}$-Ar ages had been obtained for one biotitesanidine pair (sample M80-BR from the Bristol Mountains: Tables 1 and $2 a$ ). Of the other two sanidine separates, one from the Mohave Mountains of Arizona (P81-MH, Table 2a) was dated by $\mathrm{K}-\mathrm{Ar}$ at $18.0 \mathrm{Ma}$ and the other sample, collected east of Kingman, Arizona (JP83-I40, Table 2a), never had been dated. The ${ }^{40} \mathrm{Ar} /{ }^{39} \mathrm{Ar}$ spectra were discordant and indicated possible lithic contamination. The discordant spectra are discussed below.

Samples of pumice (JN87-Ki) that appeared free of xenolithic material were collected from a Peach Springs Tuff exposure near downtown Kingman, Arizona [Buesch and Valentine, 1986, appendix, stop 2]. At this site a pocket of pumice occurs about $5 \mathrm{~m}$ above the basal contact, where the tuff overlies an early Miocene cinder cone [Buesch and Valentine, 1986]. Pumice fragments in this pocket have two appearances: the more abundant is yellow-white and 
TABLE 1. K-Ar Ages of Peach Springs Tuff

\begin{tabular}{|c|c|c|c|}
\hline Age, Ma & Mineral & Locality & Reference \\
\hline $18.8 \pm 0.6$ & san & Milkweed Canyon, Ariz. & $\begin{array}{l}\text { Young and Brennan } \\
\text { [1974] }\end{array}$ \\
\hline $17.3 \pm 0.4$ & san & Kingman, Ariz. & $\begin{array}{l}\text { Young and Brennan } \\
{[1974]}\end{array}$ \\
\hline $\begin{array}{l}18.2 \pm 0.4,18.8 \pm \\
0.5\end{array}$ & san, bio & Whipple Mountains, Calif. & Dickey et al. [1980] \\
\hline $20.0 \pm 1.0$ & san & Cady Mountains, Calif. & Glazner [1988] \\
\hline $18.1 \pm 0.6$ & san & $\begin{array}{l}\text { Chemehuevi Mountains, } \\
\text { Calif. }\end{array}$ & Howard et al. [1982] \\
\hline $18.3 \pm 0.6$ & san & $\begin{array}{l}\text { Little Piute Mountains, } \\
\text { Calif. }\end{array}$ & Howard et al. [1982] \\
\hline $\begin{array}{l}20.0 \pm 0.5,18.8 \pm \\
0.5\end{array}$ & san, bio & Woods Mountains, Calif. & Goldfarb et al. [1987] \\
\hline $\begin{array}{l}19.2 \pm 0.6,20.1 \pm \\
0.5\end{array}$ & san, bio & Bristol Mountains, Calif. & $\begin{array}{l}\text { M. A. Pernokas and J. } \\
\text { K. Nakata (written } \\
\text { communication, 1984) }\end{array}$ \\
\hline $16.5 \pm 0.4$ & san & Bristol Mountains, Calif. & $\begin{array}{l}\text { M. A. Pernokas (written } \\
\text { communication, 1982) }\end{array}$ \\
\hline $18.0 \pm 0.5$ & san & Bristol Mountains, Calif. & \\
\hline $20.5 \pm 0.5$ & san & Pinto Mountain, Calif. & $\begin{array}{l}\text { J. K. Nakata (written } \\
\text { communication, 1984) }\end{array}$ \\
\hline $16.2 \pm 0.4$ & $\operatorname{san}$ & Marble Mountains, Calif. & \\
\hline $17.6 \pm 0.5^{*}$ & san & Mohave Mountains, Ariz. & $\begin{array}{l}\text { M. A. Pernokas and J. } \\
\text { K. Nakata (written } \\
\text { communication, 1988) }\end{array}$ \\
\hline $\begin{array}{l}18.0 \pm 0.3^{*} \\
18.7 \pm 0.4^{*}\end{array}$ & $\begin{array}{l}\text { san } \\
\text { bio }+\end{array}$ & $\begin{array}{l}\text { Mohave Mountains, Ariz. } \\
\text { Mohave Mountains, Ariz. }\end{array}$ & \\
\hline $18.6 \pm 0.6$ & san & Piute Mountains, Calif. & Marvin et al. [1989] \\
\hline $17.5 \pm 0.4$ & san & Ship Mountains, Calif. & $\begin{array}{l}\text { J. K. Nakata (written } \\
\text { communication, 1983) }\end{array}$ \\
\hline
\end{tabular}

*Revised by corrections to laboratory spike calibration (J. K. Nakata, oral communication, 1988).

$\nmid$ Listed incorrectly as sanidine by Glazner et al. [1986].

coarsely vesicular, and the less abundant is grey with smaller vesicles. Both pumice types are composed of isotropic glass and contain at least $5 \%$ of clear, glassy sanidine that lacks adularescence. Sanidine separates from the yellow-white pumice were used for the ${ }^{40} \mathrm{Ar} /{ }^{39} \mathrm{Ar}$ incremental release method, and mineral grains from grey pumice lumps were used for dating by the laser fusion method. Biotite grains from the gray pumice appeared slightly iridescent, but hornblende grains appeared unaltered.

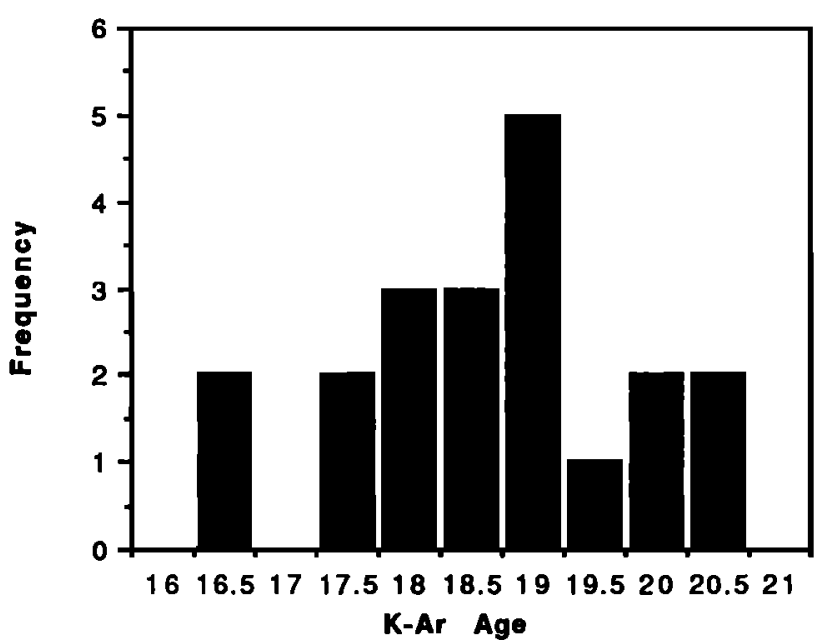

Fig. 2. Histogram of K-Ar ages from Peach Springs Tuff matrixrich samples. All data are revised to new decay constants [Dalrymple, 1979].

\section{Sample Preparation}

Separates from bulk tuff samples. Splits of previously dated mineral separates were hand-picked to provide an analytical sample of optically clear sanidine grains.

Pumice samples (JN87-Ki). Several lumps of the yellowwhite pumice provided sanidine for incremental- and totalrelease ${ }^{40} \mathrm{Ar} /{ }^{39} \mathrm{Ar}$ determinations. The pumice was crushed and sieved to isolate favorable size fractions of individual, noncomposite grains. Standard density, magnetic, and handpicking techniques were used to purify mineral separates. In all cases, purity was estimated to be greater than $99.5 \%$. For the laser fusion determinations, clean optically clear grains of sanidine, and apparently clean biotite and hornblende grains, were hand-picked from the -60 to +100 mesh fractions of two lumps of grey pumice after crushing and sieving. Sanidine grains were treated by brief etching with $5 \% \mathrm{HF}$ and $15 \% \mathrm{HNO}_{3}$, followed by thorough washing with purified water.

\section{Analytical Techniques}

The ${ }^{40} \mathrm{Ar} /{ }^{39} \mathrm{Ar}$ determinations for bulk samples. The samples were encapsulated in aluminum foil, weighed, and loaded into silica glass vials, which were then sealed. Samples were irradiated in the $\mathrm{H} 5$ facility of the Ford Nuclear Reactor at the University of Michigan. The primary flux monitor was MMhb-1, the Minnesota hornblende standard [Alexander et al., 1978]. Correction factors for Ca- and $\mathbf{K}$-derived isotopes as determined from analysis of irradiated $\mathrm{K}$ and Ca salts are ${ }^{40} \mathrm{Ar} /{ }^{39} \mathrm{Ar}(\mathrm{K})=0.0347 ;{ }^{36} \mathrm{Ar} /{ }^{37} \mathrm{Ar}(\mathrm{Ca})=$ $0.000257 ;{ }^{39} \mathrm{Ar} /{ }^{37} \mathrm{Ar}(\mathrm{Ca})=0.000749$. 
TABLE 2a. Results of ${ }^{40} \mathrm{Ar} /{ }^{39} \mathrm{Ar}$ Dating of Peach Springs Tuff Samples by Incremental Heating: Mineral Separates That Previously Were Dated by the K-Ar Method

\begin{tabular}{|c|c|c|c|c|c|c|c|}
\hline$T,{ }^{\circ} \mathrm{C}$ & ${ }^{40} \mathrm{Ar} /{ }^{39} \mathrm{Ar}$ & ${ }^{37} \mathrm{Ar} /{ }^{39} \mathrm{Ar}$ & ${ }^{36} \mathrm{Ar} /{ }^{39} \mathrm{Ar} *$ & Percent ${ }^{39} \mathrm{Ar}$ & ${ }^{40} \mathrm{Ar} \operatorname{Rad}$ & Apparent & Age, Ma \\
\hline \multicolumn{8}{|c|}{$M 80-B R$, Sanidine, $J=0.006485 \dagger$} \\
\hline 825 & 4.274 & 0.05983 & 83.56 & 3.0 & 41.4 & 20.59 & \pm 0.34 \\
\hline 915 & 1.999 & 0.02227 & 6.799 & 18.5 & 88.1 & 20.48 & \pm 0.21 \\
\hline 980 & 2.042 & 0.02176 & 7.736 & 9.0 & 87.0 & 20.66 & \pm 0.36 \\
\hline 1015 & 2.074 & 0.02072 & 8.824 & 20.1 & 85.6 & 20.66 & \pm 0.36 \\
\hline 1055 & 2.046 & 0.02089 & 7.321 & 10.4 & 87.6 & 20.84 & \pm 0.37 \\
\hline 1090 & 2.193 & 0.02066 & 10.95 & 16.7 & 83.5 & 21.31 & \pm 0.22 \\
\hline 1140 & 2.252 & 0.02035 & 11.60 & 18.1 & 83.1 & 21.77 & \pm 0.25 \\
\hline 1180 & 3.204 & 0.02048 & 42.20 & 3.5 & 59.9 & 22.32 & \pm 0.32 \\
\hline Fuse & 10.90 & 0.02463 & 295.7 & 0.7 & 19.5 & 24.67 & \pm 1.31 \\
\hline \multicolumn{6}{|c|}{$100.0 \ddagger$} & \multicolumn{2}{|c|}{$21.04 \pm 0.30 \S$} \\
\hline \multicolumn{8}{|c|}{$M 80-B R$, Biotite, $J=0.005785$} \\
\hline 560 & 7.248 & 0.3043 & 20.47 & 3.2 & 16.4 & 12.35 & \pm 2.51 \\
\hline 750 & 4.065 & 0.1166 & 7.652 & 4.1 & 43.7 & 18.46 & \pm 1.48 \\
\hline 825 & 2.801 & 0.04275 & 3.122 & 6.3 & 65.9 & 19.17 & \pm 0.26 \\
\hline 875 & 2.331 & 0.02231 & 15.88 & 7.7 & 78.5 & 18.99 & \pm 0.21 \\
\hline 925 & 2.302 & 0.01988 & 15.58 & 10.8 & 78.6 & 18.78 & \pm 0.40 \\
\hline 975 & 2.384 & 0.02021 & 14.91 & 17.0 & 80.1 & 19.83 & \pm 0.21 \\
\hline 1025 & 2.330 & 0.02197 & 10.61 & 11.5 & 85.1 & 20.59 & \pm 0.24 \\
\hline 1075 & 2.356 & 0.02175 & 11.08 & 14.4 & 84.7 & 20.71 & \pm 0.22 \\
\hline 1130 & 2.327 & 0.02353 & 10.14 & 10.7 & 85.7 & 20.70 & \pm 0.36 \\
\hline Fuse & 2.412 & 0.02787 & 11.59 & 14.5 & 84.4 & 21.13 & \pm 0.66 \\
\hline \multicolumn{6}{|c|}{$100.0 \ddagger$} & \multicolumn{2}{|c|}{$19.81 \pm 0.44 \S$} \\
\hline \multicolumn{8}{|c|}{$J P 83-140$, Sanidine, $J=0.006250$} \\
\hline 825 & 2.905 & 0.03502 & 40.24 & 4.5 & 57.8 & 18.84 & \pm 2.26 \\
\hline 925 & 1.601 & 0.02890 & 4.3294 & 3.8 & 89.7 & 16.13 & \pm 1.05 \\
\hline 980 & 1.706 & 0.02428 & 5.4249 & 12.4 & 96.9 & 18.55 & \pm 0.19 \\
\hline 1010 & 1.769 & 0.02231 & 0.6877 & 16.0 & 96.7 & 19.19 & \pm 0.21 \\
\hline 1050 & 1.820 & 0.02079 & 1.124 & 20.2 & 96.1 & 19.61 & \pm 0.23 \\
\hline 1090 & 1.924 & 0.01991 & 0.7539 & 26.6 & 96.9 & 20.89 & \pm 0.25 \\
\hline 1140 & 2.025 & 0.01908 & 4.115 & 13.5 & 92.1 & 20.92 & \pm 0.36 \\
\hline 1180 & 13.31 & 0.01984 & 376.2 & 1.9 & 16.2 & 24.10 & \pm 0.39 \\
\hline Fuse & 41.40 & 0.01803 & 1317.0 & 1.0 & 5.9 & 27.19 & \pm 3.52 \\
\hline \multicolumn{6}{|c|}{$100.0 \ddagger$} & \multicolumn{2}{|c|}{$19.93 \pm 0.41 \S$} \\
\hline \multicolumn{8}{|c|}{ P81-MH, Sanidine, $J=0.006173$} \\
\hline 800 & 3.525 & 0.4014 & 65.65 & 2.7 & 44.8 & 17.50 & \pm 0.75 \\
\hline 925 & 1.812 & 0.04404 & 3.697 & 7.0 & 92.0 & 18.47 & \pm 0.25 \\
\hline 980 & 1.786 & 0.02447 & 1.897 & 15.4 & 94.8 & 18.76 & \pm 0.21 \\
\hline 1010 & 1.781 & 0.01962 & 1.138 & 17.6 & 96.0 & 18.94 & \pm 0.21 \\
\hline 1045 & 1.818 & 0.01767 & 2.352 & 19.7 & 94.1 & 18.95 & \pm 0.24 \\
\hline 1070 & 1.908 & 0.01715 & 3.787 & 19.7 & 92.2 & 19.48 & \pm 0.24 \\
\hline 1090 & 1.977 & 0.01658 & 4.610 & 11.9 & 91.2 & 19.97 & \pm 0.25 \\
\hline 1140 & 2.083 & 0.01631 & 6.634 & 4.6 & 88.8 & 20.48 & \pm 0.36 \\
\hline Fuse & 2.835 & 0.01611 & 30.99 & 1.4 & 66.4 & 20.83 & \pm 2.31 \\
\hline \multicolumn{6}{|c|}{$100.0 \ddagger$} & \multicolumn{2}{|c|}{$19.17 \pm 0.27 \S$} \\
\hline
\end{tabular}

${ }^{*}{ }^{36} \mathrm{Ar} /{ }^{39} \mathrm{Ar}$ multiplied by $10^{4}$.

†Plateau age $20.60 \pm 0.27 \mathrm{Ma}$

$\$$ Total.

\$Mean.

Samples were heated in a molybdenum crucible within an ultrahigh vacuum extraction system, using RF induction heating. Extraction temperatures were calibrated with an optical pyrometer, and are estimated to be accurate to $\pm 50^{\circ} \mathrm{C}$. Standard gettering techniques were used to purify the inert gases. The isotopic composition of Ar was determined using a $15-\mathrm{cm}$-radius Nier-type mass spectrometer. Ages were calculated using the equations of Dalrymple et al. [1981] (Tables $2 a$ and $2 b$ ).

The analytical data were used to estimate ages using total gas, plateau, and isotope-correlation approaches. A total gas age was determined by weighting each age and its associated uncertainty based on the amount of ${ }^{39} \mathrm{Ar}(\mathrm{K})$ present in the gas increment (Tables $2 a$ and $2 b$ ). This age should be approximately equivalent to a conventional $\mathrm{K}-\mathrm{Ar}$ age. A plateau age is the mean value of all increments that are concordant, based on 2-sigma analytical uncertainties, excluding any uncertainty in the $J$ correction for factors associated with irradiation conditions [Faure, 1986]. Uncertainties associated with plateau ages are \pm 2 standard deviations about the mean, plus a $0.25 \%$ uncertainty in the $J$ value. 
TABLE 2b. Results of ${ }^{40} \mathrm{Ar} /{ }^{39} \mathrm{Ar}$ Dating of Peach Springs Tuff Samples by Incremental Heating: Sanidine Separates From Pumice Blocks-Sample JN87-Ki

\begin{tabular}{|c|c|c|c|c|c|c|c|}
\hline$T,{ }^{\circ} \mathrm{C}$ & ${ }^{40} \mathrm{Ar} /{ }^{39} \mathrm{Ar}$ & ${ }^{37} \mathrm{Ar} /{ }^{39} \mathrm{AR}$ & ${ }^{36} \mathrm{Ar} /{ }^{39} \mathrm{Ar} *$ & $\begin{array}{c}\text { Percent } \\
{ }^{39} \mathrm{Ar}\end{array}$ & ${ }^{40} \mathrm{Ar} \operatorname{Rad}$ & Apparent & t Age, Ma \\
\hline \multicolumn{8}{|c|}{ Split $A, J=0.005620$, Plateau Age $18.52 \pm 0.33 \mathrm{Ma}$} \\
\hline 700 & 11.84 & 0.09281 & 347.2 & 0.5 & 13.1 & 15.62 & \pm 5.35 \\
\hline 825 & 12.39 & 0.40125 & 367.9 & 0.5 & 12.2 & 15.25 & \pm 4.68 \\
\hline 900 & 5.917 & 0.1537 & 126.2 & 0.6 & 36.6 & 21.76 & \pm 0.33 \\
\hline 973 & 2.911 & 0.1057 & 4.118 & 0.9 & 57.3 & 16.77 & \pm 1.50 \\
\hline 1050 & 2.386 & 0.1416 & 1.844 & 1.4 & 76.2 & 18.28 & \pm 0.60 \\
\hline 1115 & 2.163 & 0.1774 & 1.650 & 0.5 & 76.5 & 16.64 & \pm 1.45 \\
\hline 1150 & 2.011 & 0.1124 & 0.7539 & 0.8 & 87.6 & 17.72 & \pm 0.35 \\
\hline 1180 & 1.969 & 0.08882 & 0.2183 & 1.3 & 95.3 & 18.87 & \pm 0.39 \\
\hline 1210 & 1.991 & 0.1139 & 0.2517 & 2.0 & 95.0 & 19.01 & \pm 0.24 \\
\hline 1240 & 2.041 & 0.07597 & 0.3945 & 8.2 & 92.7 & 19.05 & \pm 0.23 \\
\hline 1275 & 1.919 & 0.05780 & 0.1829 & 8.5 & 95.6 & 18.45 & \pm 0.30 \\
\hline 1280 & 1.920 & 0.04441 & 0.1334 & 8.4 & 96.3 & 18.60 & \pm 0.27 \\
\hline 1300 & 1.928 & 0.04031 & 0.1304 & 9.1 & 96.4 & 18.68 & \pm 0.32 \\
\hline 1315 & 1.932 & 0.02722 & 0.1913 & 7.9 & 95.4 & 18.53 & \pm 0.27 \\
\hline 1330 & 1.933 & 0.04427 & 0.2025 & 7.2 & 95.3 & 18.52 & \pm 0.22 \\
\hline 1345 & 1.924 & 0.03305 & 0.1699 & 6.8 & 95.7 & 18.52 & \pm 0.24 \\
\hline 1360 & 1.924 & 0.04961 & 0.2045 & 6.1 & 95.3 & 18.43 & \pm 0.63 \\
\hline 1375 & 1.938 & 0.04737 & 0.2935 & 6.7 & 93.9 & 18.30 & \pm 0.37 \\
\hline 1400 & 1.991 & 0.04932 & 0.3549 & 7.9 & 93.2 & 18.65 & \pm 0.23 \\
\hline 1425 & 2.160 & 0.04324 & 0.6899 & 6.6 & 89.1 & 19.35 & \pm 0.72 \\
\hline 1450 & 2.046 & 0.03663 & 0.4793 & 4.3 & 91.5 & 18.82 & \pm 0.21 \\
\hline Fuse & 2.203 & 0.02571 & 1.0816 & 3.9 & 84.0 & 18.60 & \pm 0.23 \\
\hline \multicolumn{6}{|c|}{$100.0 \dagger$} & \multicolumn{2}{|c|}{$18.61 \pm 0.39 \ddagger$} \\
\hline \multicolumn{8}{|c|}{ Split $\mathrm{B}, \mathrm{J}=0.005810$, Plateau Age $18.26 \pm 0.39 \mathrm{Ma}$} \\
\hline 750 & 12.00 & 0.4258 & 352.4 & 1.5 & 13.2 & 16.53 & \pm 1.59 \\
\hline 825 & 4.864 & 0.1356 & 104.1 & 2.7 & 36.3 & 18.39 & \pm 0.98 \\
\hline 875 & 2.937 & 0.06530 & 39.10 & 3.2 & 59.6 & 18.27 & \pm 0.58 \\
\hline 900 & 2.175 & 0.04217 & 12.62 & 2.7 & 81.4 & 18.47 & \pm 0.25 \\
\hline 925 & 1.913 & 0.03468 & 3.227 & 2.6 & 93.3 & 18.62 & \pm 0.27 \\
\hline 950 & 1.820 & 0.03253 & 0.3539 & 3.8 & 97.7 & 18.53 & \pm 0.19 \\
\hline 1025 & 1.793 & 0.02981 & 0.3170 & 5.2 & 97.8 & 18.29 & \pm 0.18 \\
\hline 1075 & 1.750 & 0.02627 & 0.2584 & 6.9 & 97.7 & 17.83 & \pm 0.18 \\
\hline 1110 & 1.777 & 0.02426 & 0.7127 & 8.6 & 97.0 & 17.97 & \pm 0.20 \\
\hline 1130 & 1.863 & 0.02261 & 2.667 & 9.3 & 94.0 & 18.26 & \pm 0.33 \\
\hline 1150 & 1.843 & 0.0213 & 2.545 & 11.0 & 94.1 & 18.09 & \pm 0.66 \\
\hline 1160 & 1.843 & 0.02062 & 1.901 & 12.1 & 95.2 & 18.29 & \pm 1.04 \\
\hline 1180 & 1.859 & 0.02052 & 3.101 & 10.5 & 93.3 & 18.09 & \pm 0.30 \\
\hline 1200 & 1.886 & 0.01956 & 2.789 & 8.4 & 93.9 & 18.46 & \pm 0.74 \\
\hline 1225 & 1.927 & 0.01942 & 4.468 & 6.7 & 91.4 & 18.37 & \pm 1.13 \\
\hline Fuse & 2.084 & 0.02187 & 8.365 & 4.8 & 86.6 & 18.81 & \pm 0.95 \\
\hline \multicolumn{6}{|c|}{$100.0 \dagger$} & \multicolumn{2}{|c|}{$18.23 \pm 0.57 \ddagger$} \\
\hline
\end{tabular}

${ }^{*}{ }^{36} \mathrm{Ar} /{ }^{39} \mathrm{Ar}$ multiplied by $10^{4}$.

$\uparrow$ Total.

†Mean.

The data have also been analyzed in terms of an isotope correlation diagram. In order to use this technique, all data are corrected for extraction line blanks and any interfering Ar isotopes that may be produced during irradiation. Following corrections, the diagram is assumed to represent a mixture in the sample of $\mathrm{Ar}$ isotopic ratios from two endmember components. One component ${ }^{39} \operatorname{Ar}(K) /{ }^{40} \operatorname{Ar}(R)$ is ${ }^{39} \mathrm{Ar}$ produced only by irradiation of ${ }^{39} \mathrm{~K}$ and ${ }^{40} \mathrm{Ar}$ from natural decay of ${ }^{40} \mathrm{~K}$. The other component ${ }^{36} \mathrm{Ar}(\mathrm{T}) /{ }^{40} \mathrm{Ar}(\mathrm{T})$ is assumed to come from ${ }^{36} \mathrm{Ar}$ and ${ }^{40} \mathrm{Ar}$ trapped in the mineral at the time of crystallization. The data are plotted as ${ }^{39} \mathrm{Ar}(\mathrm{K}) /{ }^{40} \mathrm{Ar}(\mathrm{R})$ against ${ }^{36} \mathrm{Ar}(\mathrm{T}) /{ }^{40} \mathrm{Ar}(\mathrm{T})$. Unlike an isochron diagram, the slope of the best fit line is not directly related to the age of the sample [Roddick et al., 1980]. Instead, the ordinate intercept is inverted and substituted in the age equation for the daughter-parent ratio. This is a valuable approach to interpretation of ${ }^{40} \mathrm{Ar} /{ }^{39} \mathrm{Ar}$ data because it tests the assumption that the trapped Ar components are of atmospheric composition $\left({ }^{36} \mathrm{Ar} /{ }^{40} \mathrm{Ar}=0.003384\right)$. Uncertainties in the isotope correlation age are based on the 2-sigma uncertainty in the ordinate intercept, plus $0.25 \%$ uncertainty in the $J$ value.

Laser fusion ${ }^{40} \mathrm{Ar} /{ }^{39} \mathrm{Ar}$ method. A few milligrams of the sanidine, biotite, and hornblende separates were placed in small aluminum-foil envelopes, which were stacked within a quartz reactor vial along with suitable monitors. The samples were irradiated in the $\mathrm{H} 5$ facility of the Ford Nuclear Reactor at the University of Michigan for 60 hours and received a fast neutron dose of approximately $1.5 \times 10^{18} \mathrm{nvt}$ (where $n$ is neutrons, $v$ is velocity, and $t$ is time). The flux monitor was a $27.88 \mathrm{Ma}$ sanidine separated from a rhyolite flow of the Taylor Creek Rhyolite [Elston, 1968], which was 
TABLE 3. Results of ${ }^{40} \mathrm{Ar} /{ }^{39} \mathrm{Ar}$ Dating of Peach Springs Tuff by Laser Fusion Analysis: Minerals From Pumice Blocks-Sample JN87-Ki

\begin{tabular}{|c|c|c|c|c|c|c|c|c|c|}
\hline $\begin{array}{l}\text { No. of } \\
\text { Grains }\end{array}$ & ${ }^{40} \mathrm{Ar} /{ }^{39} \mathrm{Ar}$ & ${ }^{37} \mathrm{Ar} /{ }^{39} \mathrm{Ar}$ & ${ }^{36} \mathrm{Ar} /{ }^{39} \mathrm{Ar}$ & $\begin{array}{c}{ }^{40} \mathrm{Ar} \text { Rad } \\
\times 10^{-14} \\
\mathrm{~mol}\end{array}$ & $\begin{array}{c}{ }^{40} \mathrm{Ar} \operatorname{Rad} \\
\%\end{array}$ & $\begin{array}{c}{ }^{39} \mathrm{Ar}(\mathrm{Ca}) \\
\%\end{array}$ & ${ }_{\%}^{36} \underset{\%}{\operatorname{Ar}(\mathrm{Ca})}$ & $\begin{array}{l}\text { Age } \\
\text { Ma }\end{array}$ & $\begin{array}{l}\text { s.d. } \\
\text { Ma }\end{array}$ \\
\hline \multicolumn{10}{|c|}{ Sanidine, $J=0.004528$} \\
\hline $12-15$ & 2.364 & 0.01916 & 0.0024 & 8.55 & 95.5 & 0.001 & 2.0 & 18.34 & 0.09 \\
\hline $12-15$ & 2.394 & 0.02709 & 0.000247 & 5.30 & 95.4 & 0.002 & 2.8 & 18.57 & 0.12 \\
\hline $12-15$ & 2.375 & 0.01947 & 0.000167 & 6.57 & 96.4 & 0.001 & 2.9 & 18.61 & 0.10 \\
\hline $15-20$ & 2.366 & 0.02754 & 0.000181 & 7.80 & 96.2 & 0.002 & 3.8 & 18.50 & 0.09 \\
\hline $20-25$ & 2.365 & 0.2807 & 0.000174 & 19.41 & 96.3 & 0.002 & 4.1 & 18.51 & 0.07 \\
\hline & & & & & & & & \multicolumn{2}{|c|}{$\begin{array}{l}18.51 \pm 0.10^{*} \\
18.50 \pm 0.06 \dagger\end{array}$} \\
\hline & \multicolumn{9}{|c|}{ Biotite, $J=0.004516$} \\
\hline 3 & 3.663 & 0.0735 & 0.00535 & 0.69 & 55.9 & 0.005 & 0.3 & 16.60 & 0.68 \\
\hline $10-12$ & 3.698 & 0.03601 & 0.00509 & 1.86 & 58.3 & 0.002 & 0.2 & 17.49 & 0.28 \\
\hline $12-15$ & 3.494 & 0.03123 & 0.00403 & 3.80 & 64.9 & 0.002 & 0.2 & 18.39 & 0.16 \\
\hline $12-15$ & 3.451 & 0.04736 & 0.00391 & 4.41 & 65.5 & 0.003 & 0.3 & 18.32 & 0.15 \\
\hline $12-15$ & 3.866 & 0.06056 & 0.00547 & 2.83 & 57.3 & 0.004 & 0.3 & 17.96 & 0.20 \\
\hline $15-20$ & 3.492 & 0.06119 & 0.00376 & 7.15 & 67.2 & 0.004 & 0.4 & 19.01 & 0.12 \\
\hline & & & & & & & & \multirow{2}{*}{\multicolumn{2}{|c|}{$\begin{array}{l}17.96 \pm 0.84^{*} \\
18.40 \pm 0.08^{\dagger}\end{array}$}} \\
\hline \multirow{2}{*}{\multicolumn{10}{|c|}{ Hornblende, $J=0.004504$}} \\
\hline & & & & & & & & & \\
\hline $20-25$ & 3.506 & 4.941 & 0.00628 & 0.23 & 56.4 & 0.3 & 19.7 & 16.06 & 2.00 \\
\hline $20-30$ & 3.509 & 4.588 & 0.00612 & 0.88 & 57.1 & 0.3 & 18.8 & 16.25 & 0.54 \\
\hline $20-30$ & 3.665 & 4.405 & 0.0063 & 0.89 & 57.1 & 0.3 & 17.5 & 16.96 & 0.55 \\
\hline & & & & & & & & \multicolumn{2}{|c|}{$\begin{array}{l}16.42 \pm 0.47^{*} \\
16.57 \pm 0.38 \dagger\end{array}$} \\
\hline
\end{tabular}

Decay constants: $\lambda_{B}=4.962 \times 10^{-10} \mathrm{yr}^{-1} ; \lambda_{e}=0.581 \times 10^{-10} \mathrm{yr}^{-1}$. Errors in individual ages do not include errors in $J$, which are estimated to be approximately $1 \%$. Reactor corrections: ${ }^{36} \mathrm{Ar} /{ }^{37} \mathrm{Ar}(\mathrm{Ca})=0.000251 ;{ }^{39} \mathrm{Ar} /{ }^{37} \mathrm{Ar}(\mathrm{Ca})=0.000671 ;{ }^{40} \mathrm{Ar} /{ }^{39} \mathrm{Ar}(\mathrm{K})=0.0380$. Weighting for weighted means is by the inverse of the variance.

$*$ Mean and s.d.

†Weighted mean and s.d.

cross-calibrated with MMhb-1 and with SB-3, the U.S. Geological Survey intralaboratory biotite standard.

Fusion of the grains was performed on the GLM continuous laser system, which consists of a 5-W Ar-ion laser, beam focussing and steering optics, observing optics, a small extraction system, and an ultra-clean mass spectrometer with Baur-Signer source and electron multiplier. Following irradiation, a few grains of the minerals and standards were placed in the sample chamber of the GLM and analyzed using methods previously described by Dalrymple and Duffield [1988] and Dalrymple [1989]. Between 3 and 30 grains were fused for each total fusion analysis; estimated sample weights ranged from 0.002 to $0.200 \mathrm{mg}$.

The results of the laser analyses are shown in Table 3. Errors for the individual analyses are estimated standard deviations of precision and do not include the error of the $J$ value, which we estimate to be approximately $1 \%$ owing to the very large horizontal flux gradients in the H5 facility. For each mineral we have calculated both a simple and a weighted mean and standard deviation [Taylor, 1982]. The results for the sanidine are so uniform that the choice of which statistic to use is immaterial. However, for the biotite and hornblende samples we prefer to use the weighted mean because it takes into account the variable qualities of the individual analyses.

\section{OBSERVATIONS}

\section{The ${ }^{40} \mathrm{Ar} /{ }^{39} \mathrm{Ar}$ Results for Bulk Separates}

Previously dated samples. All separates from bulk tuff samples are characterized by discordant ${ }^{40} \mathrm{Ar} /{ }^{39} \mathrm{Ar}$ age spec- tra; examples are shown in Figures $3 a$ and $3 b$. The early increments have low apparent ages relative to those for later increments. A wide range in ages is present in most samples. For example, the ages for JP83-I40 range from $16.13 \mathrm{Ma}$ in the earliest increment to $27.19 \mathrm{Ma}$ in the last increment (Figure 3a).

Sanidine from pumice. Duplicate analyses of sanidine separates from pumice (JN87-Ki) produced essentially concordant spectra. Both spectra are characterized by some irregularities in early increments but have plateaus formed by large proportions of the total gas (split A, 68.6\% and split B, $58.0 \%$ of total ${ }^{39} \mathrm{Ar}$, Figure $4 a$ ). The two plateau ages are $18.52 \pm 0.33$ and $18.26 \pm 0.39$ Ma. The isotope correlation diagrams for both runs are highly correlated and define ages of $18.60 \pm 0.47$ and $18.33 \pm 0.33 \mathrm{Ma}$ (Figure $4 b$ ). The trapped Ar component in both cases appears to be atmospheric in composition: $0.003379 \pm 66$, and $0.003422 \pm 118$, respectively (atmospheric ${ }^{36} \mathrm{Ar} /{ }^{40} \mathrm{Ar}=0.003384$ ). The mean of plateau and isotope correlation ages of the two samples is $18.43 \pm 0.33 \mathrm{Ma}$

\section{The ${ }^{40} \mathrm{Ar} /{ }^{39}$ Ar Laser Fusion Results}

Sanidine from pumice. The most precise age of the Peach Springs Tuff was produced by laser fusion analysis for the sanidine separate. The results have a simple mean of $18.51 \pm 0.10$ (1-sigma) Ma and a weighted mean of $18.50 \pm$ $0.06 \mathrm{Ma}$. Inclusion of the $1 \%$ uncertainty in the value of $J$ results in a best age for eruption of the Peach Springs Tuff of $18.5 \pm 0.18$. These results are essentially identical to the ages produced by the incremental heating technique. 

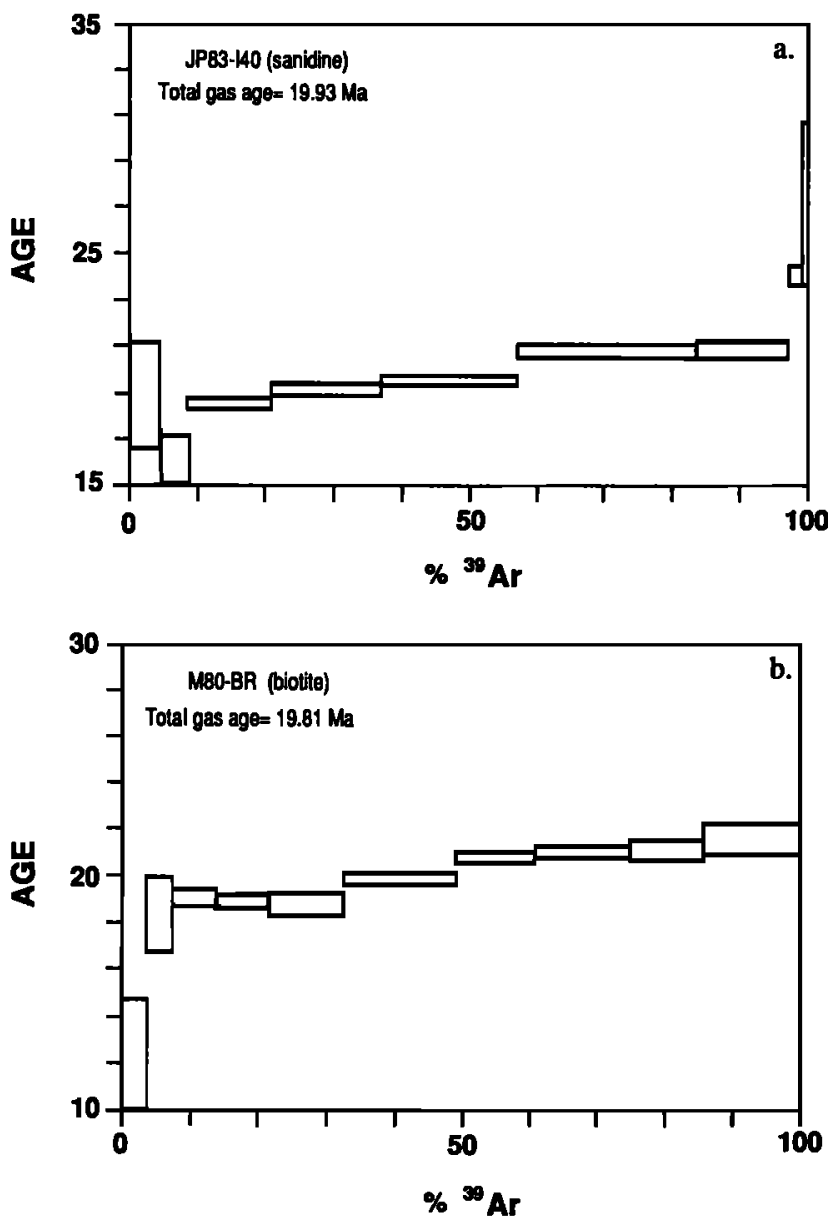

Fig. 3. Incremental release spectra of mineral separates from bulk tuff. (a) Sanidine from near Kingman (sample JP83-140, previously undated). (b) Incremental release spectrum of biotite from the Bristol Mountains (sample M80-BR, previously dated by the K-Ar method).

Mafic minerals from pumice. The weighted mean age produced for biotite separates is $18.40 \pm 0.08$, which is not significantly different from the sanidine mean age at the $95 \%$ level of confidence. However, the ages of individual analyses range from 16.60 to $19.01 \mathrm{Ma}$ and show more scatter than can be ascribed to analytical error. The hornblende ages have a weighted mean of $16.57 \pm 0.38$. These results are both internally inconsistent and 8-13\% lower than the age of the sanidine.

\section{Discussion}

\section{Age of the Peach Springs Tuff}

The age spectra and intercept of isotopic correlation diagrams demonstrate that the sanidine from the Peach Springs Tuff pumice is both undisturbed and contains no inherited ${ }^{40} \mathrm{Ar}$. The mean age of $18.43 \pm 0.33 \mathrm{Ma}$ from the incremental release data is not significantly different from either the simple or weighted mean ages of $18.51 \pm 0.10$, and $18.50 \pm 0.06$ derived from laser fusion analysis. We prefer to include a $1 \%$ uncertainty in $J$ due to reactor flux gradients and propose that the age of $18.50 \pm 0.18 \mathrm{Ma}$ (rounded to 18.5 \pm 0.2 ) for the sanidine is the likely age of emplacement of the Peach Springs Tuff.

\section{Sources of Variation in Dating of the Peach Springs Tuff}

Mineral separates from bulk samples. There are several plausible explanations for incremental release spectra that characterize the mineral separates from bulk tuff samples (Figure 3 and Table 2). These explanations include loss of ${ }^{40} \mathrm{Ar}$, retention of extraneous ${ }^{40} \mathrm{Ar}$, and contamination by older material. The spectra that climb to older ages throughout incremental Ar releases are similar to those exhibited by samples that have largely outgassed during a thermal event later than the initial crystallization of the rock [Turner, 1968]. This interpretation would mean that the Peach Springs Tuff is older than $27 \mathrm{Ma}$, the apparent age of the oldest increment for any of the samples. However, in the central Mojave Desert and the Colorado River valley the Peach Springs Tuff overlies rocks with ages as young as 19.1 Ma [Carr et al., 1980; Nielson, 1986; Glazner, 1988, 1989; Glazner et al., 1989; M. A. Pernokas and J. K. Nakata, written communication, 1988]; these data preclude such an old age for the ash flow unit. The age of the Peach Springs Tuff reported here accords well with its stratigraphic position relative to other dated rocks in these Miocene sections.

We suspect that the discordant age spectra are the result of a two-component K-feldspar mixture: an endogenous $\mathrm{K}$-feldspar and an older disturbed K-feldspar, which were indistinguishable in a hand-picked analytical sample of apparently clear and clean grains. The undisturbed endogenous K-feldspar uniformly released radiogenic ${ }^{40} \mathrm{Ar}$ and ${ }^{39} \mathrm{Ar}$ derived from $\mathbf{K}$ during incremental heating. However, radiogenic ${ }^{40} \mathrm{Ar}$ was released from the older thermally disturbed feldspar only at higher temperatures. The rising age spectrum (Figure $3 a$ ) is the sum of these two release patterns [LoBello et al., 1987].

Field observations of the Peach Springs Tuff at many localities indicate that older (Proterozoic to Mesozoic) lithic and xenocrystic contamination is widespread in the unit. Most of this contamination probably occurred by incorporation of regolith that mantled ground surfaces traversed by the tuff during emplacement [Buesch, 1988]. Release of the lower-temperature gas increments could have occurred during incorporation of the older feldspar grains in the ignimbrite. Older ages that were determined by the K-Ar method on both biotite and sanidine separates indicate that contaminant minerals included both biotite and K-feldspar.

Mafic minerals from pumice. Variation of the laser fusion ages on biotite and hornblende from pumice indicate both alteration of the minerals and derivation from older rocks. The low and inconsistent ages of hornblende clearly are due to vapor phase alteration and/or weathering, and the low ages found for some biotite samples also suggest alteration. However, values at the high range of biotite ages can be accounted for only by the presence of grains with inherited ${ }^{40} \mathrm{Ar}$.

Ages as old as 19.01 Ma are too young to be produced by partial outgassing of minerals of Proterozoic to Mesozoic ages incorporated into the tuff during emplacement. Also, nearly complete outgassing of significantly older minerals is highly unlikely to have occurred in the flowing ignimbrite [Dalrymple, 1964; Gillespie et al., 1983]. Partly degassed older Tertiary minerals could produce these ages, but xenocrystic biotite grains derived from pumice lumps more likely were incorporated in the magma before eruption. Primary evidence that xenocrystic material existed in the magma 

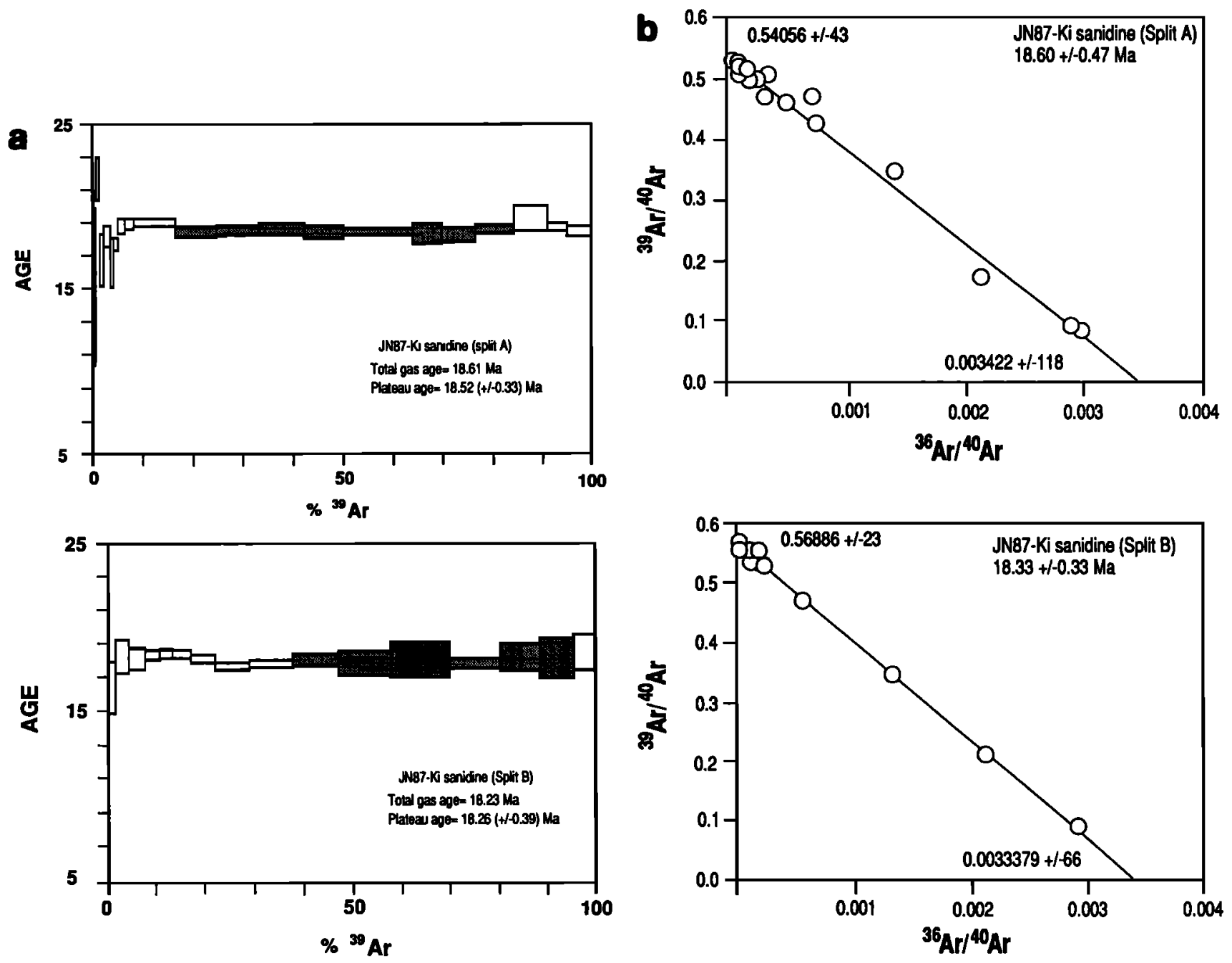

Fig. 4. The ${ }^{40} \mathrm{Ar} /{ }^{39} \mathrm{Ar}$ incremental release data for sanidine from pumice blocks. (a) $\mathrm{The}{ }^{40} \mathrm{Ar} /{ }^{39} \mathrm{Ar}$ incremental release spectra of sanidine from sample JN87-Ki (two splits). Shaded increments were used to calculate the plateau age for each sample. (b) Isotopic correlation diagrams plotted for the sanidine data.

chamber is reported by D. C. Buesch (oral communication, 1987), who has observed sanidine overgrowths on apparently plutonic K-feldspars in thin sections of the Peach Springs Tuff. Thus the biotite sample dated by laser fusion probably included xenocrysts that nearly completely outgassed in the magma chamber, as well as juvenile grains. Both kinds of biotite probably were altered after emplacement of the tuff.

The ${ }^{40} \mathrm{Ar} /{ }^{39} \mathrm{Ar}$ techniques used to date the Peach Springs Tuff offer several advantages over the conventional K-Ar method. One is the ability to recognize an older component in samples of bulk tuff by the incremental heating method, and in small samples of mafic minerals by the laser fusion technique. Another is the ability to reliably date sanidine by these methods. We interpret the K-Ar ages on sanidine that are younger than our best estimate to incomplete extraction of radiogenic ${ }^{40} \mathrm{Ar}$. McDougall and Harrison [1988] suggest that at minimum, a heating time of $45 \mathrm{~min}$ at $1600^{\circ} \mathrm{C}$ is required to quantitatively extract ${ }^{40} \mathrm{Ar}$ from high-temperature feldspars. This conclusion is supported further by the lack of anomalously young total gas ages for sanidine analyzed both by incremental heating and laser fusion.

\section{CONCLUSIONS}

Concordant ${ }^{40} \mathrm{Ar} /{ }^{39} \mathrm{Ar}$ age determinations for sanidines from pumice blocks of the Peach Springs Tuff indicate an age of $18.5 \pm 0.2 \mathrm{Ma}$, from both incremental heating and laser fusion techniques. We consider this age the best estimate for the time of eruption of the tuff. Field and petrographic observations of the Peach Springs Tuff demonstrate that bulk samples are contaminated by xenocrysts of both $\mathrm{K}$ feldspar and biotite. This could explain the release spectra of sanidine separates, which climb to older ages in hightemperature fractions. The fact that the older ages reach 27 Ma implies that the contaminant is at least that old.

Sanidine separated from two kinds of Peach Springs Tuff pumice have concordant ages, determined by two analytical methods, and display no evidence of either thermal disturbance or the presence of older components. This suggests that the contamination that likely produced old K-Ar ages for the Peach Springs Tuff occurred during emplacement of the ignimbrite. We thus endorse the conclusion of Hildreth and Mahood [1985], who stressed the importance of using minerals "separated from pumice blocks or fiamme, not the 
easily contaminated matrix" of tuff for dating. Our results indicate that sanidine is better than mafic minerals for dating pumice from Miocene tuff deposits, which probably underwent vapor-phase alteration and weathering after deposition.

We infer that most grains of contaminant minerals which contribute to spuriously old ages come from detritus incorporated during deposition of the ignimbrite, although incorporation of some older material probably occurred in the magma chamber. Eventual identification of the Peach Springs Tuff source will help to clarify this hypothesis. The identification of several probable stages of contamination emphasizes the value of both the ${ }^{40} \mathrm{Ar} /{ }^{39} \mathrm{Ar}$ incremental heating and laser fusion techniques in the recognition of the causes of variation in dates from igneous rocks.

Acknowledgments. The authors thank David Buesch for recommending productive sites to sample Peach Springs Tuff pumice, David Miller for providing previously dated sanidine and biotite separates from the Bristol Mountains of California, and David West and Dennis Sorg for separation and purification of minerals used in incremental heating and laser fusion analyses, respectively. Thanks also to Gary Cook and the staff of The University of Michigan reactors. Reviews by Marvin Lanphere, Ray Wells, Calvin Miller, and Larry Snee helped us to clarify the presentation. A. F. Glazner was supported in part by the National Science Foundation, grant EAR-8219032.

\section{REFERENCES}

Alexander, E. C., Jr., G. M. Michelson, and M. A. Lanphere, MMhb-1: A new ${ }^{40}$ Ar $/{ }^{39}$ Ar dating standard, Short Papers of the Fourth International Conference, Geochronology, Cosmochronology, and Isotope Geology, edited by R. E. Zartman, U.S. Geol. Surv. Open File Rep., 78-701, 6-8, 1978.

Buesch, D. C., Changes in depositional environments resulting from the emplacement of large-volume pyroclastic flows, Geol. Soc. Am. Abstr. Programs, 20, A178, 1988.

Buesch, D. C., and G. A. Valentine, Peach Springs Tuff and volcanic stratigraphy of the southern Cerbat Mountains, Kingman, Arizona, in Cenozoic Stratigraphy, Structure, and Mineralization in the Mojave Desert, Guideb., Trips 5 and 6, compiled by P. E. Ehlig, pp. 7-14, Cordilleran Section, Geological Society of America, Fresno, Calif., 1986.

Carr, W. J., and D. D. Dickey, Geologic map of the Vidal California, and Parker SW, California-Arizona quadrangles, San Bernardino County, California, scale 1:24,000, U.S. Geol. Surv., Misc. Invest. Ser. Map, I-1125, 1980.

Carr, W. J., D. D. Dickey, and W. D. Quinlivan, Geologic map of the Vidal NW, Vidal Junction, and parts of the Savahia Peak SW and Savahia Peak quadrangles, San Bernardino County, California, scale 1:24,000, U.S. Geol. Surv., Misc. Invest. Ser. Map, I-1126, 1980.

Dalrymple, G. B., Argon retention in a granitic xenolith from a Pleistocene basalt, Sierra Nevada, California, Nature, 201, 282, 1964.

Dalrymple, G. B., Critical tables for conversion of $\mathrm{K}-\mathrm{Ar}$ ages from old to new constants, Geology, 7, 558-560, 1979.

Dalrymple, G. B., The GLM continuous laser system for ${ }^{40} \mathrm{Ar} /{ }^{39} \mathrm{Ar}$ dating: Description and performance characteristics, U.S. Geol. Surv. Bull., 1890, 89-96, 1989.

Dalrymple, G. B., and W. A. Duffield, High precision ${ }^{40} \mathrm{Ar} /{ }^{39} \mathrm{Ar}$ dating of Oligocene rhyolites from the Mogollon-Datil volcanic field using a continuous laser system, Geophys. Res. Lett., 15, 463-466, 1988.

Dalrymple, G. B., E. C. Alexander, Jr., M. A. Lanphere, and G. P. Kraker, Irradiation of samples for ${ }^{40} \mathrm{Ar} /{ }^{39} \mathrm{Ar}$ dating using the Geological Survey TRIGA reactor, U.S. Geol. Surv. Prof. Pap., 1176, 55 pp., 1981.

Davis, G. A., Tectonic implications of variable southwestward tilts in Tertiary upper-plate strata of a Miocene detachment terrane, southeastern California and west-central Arizona, Geol. Soc. Am. Abstr. Programs, 18, 98, 1986.
Dibblee, T. W., Jr., Geologic map of the Lavic quadrangle, San Bernardino County, California, scale 1:62,500, U.S. Geol. Surv. Misc. Invest. Ser. Map, I-472, 1966.

Dibblee, T. W., Jr., and A. M. Bassett, Geologic map of the Cady Mountains quadrangle, San Bernardino County, California, scale 1:62,500, U.S. Geol. Surv. Misc. Invest. Ser. Map, I-467, 1966.

Dickey, D. D., W. J. Carr, and W. B. Bull, Geologic map of the Parker NW, Parker, and parts of the Whipple Mountains SW and Whipple Wash quadrangles, California and Arizona, scale 1: 24,000, U.S. Geol. Surv. Misc. Invest. Ser. Map, I-1124, 1980.

Durrell, C., Celestite deposits near Ludlow, San Bernardino, California, Spec. Rep. Calif. Div. Mines Geol., 32, 37-48, 1953.

Elston, W. E., Terminology and distribution of ignimbrites of the Mogollon-Silver City-Lordsburg region New Mexico, in Southern Arizona Guidebook III, edited by S. R. Titley, pp. 231-240, Arizona Geological Society, Tucson, 1968.

Faure, G., Principles of Isotope Geology, 2nd ed., 589 pp., John Wiley, New York, 1986.

Gillespie, A. R., J. C. Huneke, and G. J. Wasserburg, Eruption age of a Pleistocene basalt from ${ }^{40} \mathrm{Ar} /{ }^{39} \mathrm{Ar}$ analysis of partially degassed xenoliths, J. Geophys. Res., 88, 4997-5008, 1983.

Glazner, A. F., Cenozoic evolution of the Mojave block and adjacent areas, Ph.D. dissertation, 175 pp., Univ. of Calif., Los Angeles, 1981.

Glazner, A. F., Stratigraphy, structure, and potassic alteration of Miocene volcanic rocks in the Sleeping Beauty area, central Mojave Desert, California, Geol. Soc. Am. Bull., 100, 424-435, 1988.

Glazner, A. F., Recycling of continental crust in Miocene volcanic rocks from the Mojave block, southern California, Mem. Geol. Soc. Am., 174, in press, 1989.

Glazner, A. F., J. E. Nielson, K. A. Howard, and D. M. Miller, Correlation of the Peach Springs Tuff, a large-volume Miocene ignimbrite sheet in California and Arizona, Geology, 14, 840-843, 1986.

Glazner, A. F., J. M. Bartley, and J. D. Walker, Magnitude and significance of Miocene crustal extension in the central Mojave Desert, California, Geology, 17, 50-53, 1989.

Goff, F. E., A. C. Eddy, and B. H. Amey, Reconnaisance geologic strip map from Kingman to south of Bill Williams Mountain, Arizona, scale 1:24,000, Map LA-9202, Los Alamos Natl. Lab., Los Alamos, N. M., 1983.

Goldfarb, R., D. M. Miller, R. W. Simpson, D. B. Hoover, P. Moyle, J. E. Olson, and R. S. Gaps, Mineral Resources of the Providence Mountains Wilderness study area, San Bernardino County, California, U.S. Geol. Surv. Bull., 1712-D, 33 pp., 1987. Gusa, S., J. E. Nielson, and K. A. Howard, Heavy mineral suites confirm the wide extent of the Peach Springs Tuff in California and Arizona, U.S.A., J. Volcanol. Geotherm. Res., 33, 343-347, 1987.

Hildreth, W. A., and G. Mahood, Correlation of ash-flow tuffs, Geol. Soc. Am. Bull., 96, 968-974, 1985.

Howard, K. A., and B. E. John, Crustal extension along a rooted system of low-angle normal faults, Colorado River extensional corridor, California and Arizona, Continental Extensional Tectonics, edited by M. P. Coward, J. F. Dewey, and P. L. Hancock, Spec. Publ. Geol. Soc. London, 28, 299-311, 1987.

Howard, K. A., P. Stone, M. A. Pernokas, and R. F. Marvin, Geologic and geochronologic reconnaissance of the Turtle Mountains area California: West border of the Whipple detachment terrane, in Mesozoic-Cenozoic Tectonic Evolution of the Colorado River Region, California, Arizona, and Nevada, edited by E. G. Frost and D. L. Martin, pp. 341-354, Cordilleran Publishers, San Diego, Calif., 1982.

LoBello, P., G. Ferand, C. M. Hall, D. York, P. Lavina, and M. Bernat, ${ }^{40} \mathrm{Ar} /{ }^{39} \mathrm{Ar}$ step-heating and laser fusion dating of a Quaternary pumice from Neschers Massif, Central France: The defeat of xenocrystic contamination, Chem. Geol., 66, 61-71, 1987.

Marvin, R. F., H. H. Mehnert, and C. W. Naeser, U.S. Geological Survey radiometric ages-Compliation " $\mathrm{C}$ ", part three, California and Nevada, Isochron West, 52, 3-11, 1989.

McDougall, I., and T. M. Harrison, Geochronology and Thermochronology by the ${ }^{40} \mathrm{Ar}{ }^{39} \mathrm{Ar}$ Method, 212 pp., Oxford University Press, New York, 1988.

Nielson, J. E., Miocene stratigraphy of the Mohave Mountains, Arizona, and correlation with adjacent ranges, in Cenozoic 
Stratigraphy, Structure, and Mineralization in the Mojave Desert, Guideb., Trips 5 and 6, compiled by P. E. Ehlig, pp. 15-24, Cordilleran Section, Geological Society of America, Fresno, Calif., 1986.

Nielson, J. E., A. F. Glazner, and D. R. Lux, Problems of dating the Peach Springs Tuff, Geol. Soc. Am. Abstr. Programs, 20, 218, 1988.

Pike, J. E. Nielson, and V. L. Hansen, Complex Tertiary stratigraphy and structure, Mohave Mountains, Arizona: A preliminary report, in Mesozoic-Cenozoic Tectonic Evolution of the Colorado River Region, California, Arizona, and Nevada, edited by E. G. Frost and D. L. Martin, pp. 91-96, Cordilleran Publishers, San Diego, Calif., 1982.

Roddick, J. C., R. A. Cliff, and D. C. Rex, The evolution of excess argon in alpine biotites- $-{ }^{40} \mathrm{Ar} /{ }^{39} \mathrm{Ar}$ analysis, Earth Planet. Sci. Lett., 48, 185-208, 1980.

Suneson, N. H., The origin of biomodal volcanism, west-central Arizona, Ph.D. dissertation, 293 pp., Univ. of Calif., Santa Barbara, 1980.

Suneson, N. H., and I. Lucchitta, K-Ar ages of Cenozoic volcanic rocks, west-central Arizona, Isochron West, 24, 25-29, 1979.

Taylor, J. R., An Introduction to Error Analysis, 270 pp., University Science Books, Mill Valley, Calif., 1982.

Turner, G., The distribution of potassium and argon in chondrites, in Origin and Distribution of the Elements, edited by L. H. Ahrens, pp. 387-398, Pergamon, New York, 1968.

Valentine, G. A., D. C. Buesch, and R. V. Fisher, Basal layered deposits of the Peach Springs Tuff, northwestern Arizona, Bull. Volcanol., in press, 1989.

Wells, R. E., and J. W. Hillhouse, Paleomagnetism and tectonic rotation of the lower Miocene Peach Springs Tuff-Colorado Plateau, Arizona, to Barstow, California, Geol. Soc. Am. Bull., $101,846-863,1989$.

Young, R. A., Cenozoic geology along the edge of the Colorado Plateau in northwestern Arizona, Ph.D. dissertation, 167 pp. Wash. Univ., St. Louis, Mo., 1966.

Young, R. A., and W. J. Brennan, Peach Springs Tuff: Its bearing on structural evolution of the Colorado Plateau and development of Cenozoic drainage in Mohave County, Arizona, Geol. Soc. Am. Bull., 85, 83-90, 1974.

G. B. Dalrymple, U.S. Geological Survey, 345 Middlefield Road, MS 937, Menlo Park, CA 94025.

A. F. Glazner, Department of Geology, CB 3315, University of North Carolina, Chapel Hill, NC 27599.

D. R. Lux, Department of Geological Sciences, University of Maine, Orono, ME 04469.

J. E. Nielson, U.S. Geological Survey, 345 Middlefield Road, MS 975, Menlo Park, CA 94025.

(Received February 28, 1989; revised June 19, 1989; accepted May 16, 1989. 